\title{
New Face of Local Government: Synergy of Handling the Spread of \\ Covid-19 Between Local Governments and Indigenous Villages in Bali
}

\author{
I Putu Dharmanu Yudartha \\ Department of Public Administration Udayana University (email: p_dharmanu@unud.ac.id)
}

\begin{abstract}
Province Bali province seeks to build synergy in addressing the spread of covid-19 with the involvement of indigenous villages. This is certainly a big question about its effectiveness and provides a new perspective in government governance at the local level. The purpose of this research is to analyze the dimensions of synergy between local governments and indigenous villages in Bali Province and their impact on the handling of covid-19 in Bali. The results showed that the cultural and social dimensions were able to position the indigenous village into an important pillar in the pattern of governance in Bali. Through the policy of the scope of indigenous villages (such as awig-awig and perarem) and pecalang as a security party in the scope of indigenous villages are able to synergize with local governments, especially in overseeing the implementation of health protocols. The synergistic with good local governance concept, such as : dimension of the economic aspect shows that through indigenous village funds, the local government provides the same space for indigenous villages involved in the handling of covid-19. The political dimension related to synergy is further strengthening the commitment of the Governor of Bali to reposition the indigenous village as part of governance in Bali. The synergistic impact is to provide great space for various parties, especially indigenous villages in the participation of each policy in the region. This synergy also relieves the free local government in its handling of covid-19.
\end{abstract}

\section{Keywords:}

Synergy; local government; indigenous villages

\section{Introduction}

Governance in Bali province has different uniqueness and dynamics when compared to other regions. Bali has historically had a indigenous village (pakraman) that has been around since the time of the kingdom. Until now, the existence of indigenous villages in Bali has an interesting dynamic. The civility of the indigenous village that juxtaposes the village service (village government) gives its own 'color' in the governance order in Bali. Enactment of law no. 6/2014 on Villages, providing fundamental changes to governance especially between village services (village government) and indigenous villages. The law positions the village government into a registered village, because in article 6 of law no. 6 of 2014 requires 
that to prevent the spillage of territory, authority, institutional duplication then in 1 (one) area there are only villages or indigenous villages. Then institutionally the government, prior to the enacting of law number 6 of 2014, the position of the indigenous village in various activities is generally aligned (coordination relationship) with the village office (Windia, 2017). After the enactment of law number 6 of 2014 the existence of indigenous villages inclined to be under (sub-coordinating relations) of village government.

The village's legal policy provides polemic to indigenous villages in Bali, where the existence of indigenous villages experiences 'degradation' of values and relationships especially between service villages and indigenous villages. These conditions encouraged strengthening the policy on indigenous villages in Bali. In 2019, the emergence of local regulations of Bali province number 4 of 2019 on indigenous villages in Bali. By definition the indigenous village as a unit of indigenous legal people based on the philosophy of Tri Hita Karana rooted in local wisdom Sad Kerthi, imbued with Hindu teachings and local cultural values and wisdom living in Bali, is so big a role in the development of people, nations, and countries that it needs to be protected, fostered, developed, and empowered to realize the life of the politically sovereign, economically cultivated, and personal Balinese Krama in culture. The governance of the law, the indigenous village can conduct relations with the central government up to the level of non-governmental organizations and community organizations. The governance in question is authoritative, coordinated and consultative. In general the relationship between the village and the indigenous village performs almost the same task, Only the thing that indigenous village distinguishes is in the implementation of the origin, related to the value, culture, customs and arrangement of the implementation based on the original arrangement (Mulyanto, 2015)

The existence of indigenous villages in Bali Province is about 1,488 compared to the number of village services (village government). These conditions provide their own uniqueness but also challenges and opportunities in positioning indigenous villages as part of governance especially in supporting policies or programs in the scope of Bali Province. The covid-19 pandemic in Bali demands optimal and effective performance in suppressing the spread and implementing health protocols. Technically enactment of Local Regulation of Bali Province No. 4 of 2019, providing opportunities for indigenous villages involved in supporting the policies of the Provincial Government of Bali and the district or city in Bali. 
By definition in terms of governance, according to Rhodes (1996) offers a baseline definition leaning on Sammy (1970), "government is defined as: the activity or process of governing or governance, a condition or ordered rule, those people charged with the duty of governing or governors, and the manner method or system by which a particular society is governed" (Alhabil, 2011). Relations or intergovernmental relations are essentially in line with the concept of decentralization based on several characteristics (Wijayanti, 2016), namely:

Territorial decentralization, submission of government affairs or the granting of authority to conduct a government matter from a higher government to a lower unit of government organizations based on regional aspects.

1. Functional decentralization, i.e. the surrender of government affairs or the granting of authority to conduct a government matter from a higher government to lower government units based on aspects of its purpose.

2. Political decentralization, i.e. the immunization of authority that gives rise to the right to take care of the household's own interests for political bodies in the regions chosen by the people. It is also related to territorial decentralization.

3. Cultural Decentralization, i.e. granting rights to certain groups to organize their own cultural activities.

4. Decentralization of the economy, i.e. the immunization of authority in the implementation of economic activities; Administrative decentralization, i.e. the immunization of some authority to self-government tools or units in the region. His understanding is synonymous with deconcentration.

The relationship of the governance of the Government of Bali Province with the indigenous village becomes an interesting study for analysis. Especially in conducting a critical analysis of the role and authority given to indigenous villages in countering the covid19 pandemic. Based on the above statement, the formula of the problem is how the pattern of relations and synergy between the government in Bali and the indigenous village.

\section{Methods}

The research approach of this exploratory study is the critical analysis in relations between local government and indigenous villages. Focus research seeks to analyze related to 
the handling of covid-19 pandemic, especially the authority of indigenous village. Secondary data-driven data collection through library studies.

\section{Results and Discussion}

The findings in the field show that the pattern of relationship between indigenous villages and the Government of Bali Province, refers to local regulation number 4 of 2019 on indigenous villages. The local regulation is the actualization of law number 23 of 2014 on local government. This shows that in policy, the position of indigenous villages becomes part of the local government specifically in the government of Bali Province. This means that the position of the indigenous village is not part of village law number 6 of 2014, so the position of the indigenous village is not part of the village government (village service). Indigenous villages have an equal position in the context of coordination and supporting in policy implementation.

The position of the indigenous village becomes an interesting study if it takes a good governance perspective or perspective. Discussing good governance is very complex because of the diverse perspectives, criteria and meanings regarding good governance. Consequently establishing a good governance and brought in the autonomy of indigenous villages in Bali becomes a challenge in itself. The perspective that the authors use is certainly related to the response to the covid-19 pandemic, especially in Bali Province. Surely every indigenous village in Bali has different policies based on local values, culture and wisdom (awig-awig and perarem). It becomes interesting if the concept of good governance is associated with synergy carried out by the Balinese provincial government and indigenous villages in Bali. Surely, there are differences in perception and meaning in building commitment and opening up the participation of all elements in the region to be obstacles not to mention the cultural or cultural problems of our society because good governance develops in developed countries that are not necessarily appropriate or can be created here. Apart from the various polemics that exist let's look at the view of Garry Stocker who was called the first founder of good governance. With five concepts about good governance (Putra, 2005:74) namely:

1. Utilization of a set of institutions and actors both inside and outside government; In this rule, it is stated in local regulation number 4 of 2019, where indigenous villages are given authority in working with government agencies ranging from central to 
community groups, as well as vice versa. This means there is a large space for indigenous villages in particular to build indigenous villages based on synergy with a set of institutions. In relation to the handling of covid-19, the Bali provincial government engaged all components of the indigenous village to be involved in handling health protocols, especially to indigenous villagers (krama).

2. The combined power of government, private sector and society;

This has explicitly been done by indigenous villages in Bali, especially in the field of tourism. Indigenous villages develop a lot of tourism potential by engaging private parties in the provision of accommodation as well as the community as the party that manages the tourist attractions. Especially in the handling of covid-19, indigenous villages are included in local organizations and have a cultural and communal attachment to indigenous peoples. This caused the implementation of health protocols to run properly, where the indigenous village positioned the security of indigenous villages (pecalang) in assisting the duties of health workers and police.

3. The Mutual relationship hangs between the three powers; The relationship between local governments including indigenous villages, with private parties and communities is an opportunity to suppress the spread of covid-19 in Bali. For example, in every religious activity involving many people, the indigenous village council in Bali Province issued a circular. The call through the circular seeks to regulate the ritual implementation technique in order to maintain health protocols (Balipost, 2020). On the other hand, indigenous villages cooperate with private parties, especially the managers of tourist attractions, hotels, restaurants and other accommodation located in the area of the indigenous village in the implementation of health protocols. This aims to suppress the spread of covid-19, especially from tourists visiting tourist attractions in Bali.

4. The formation of a separate network between the three forces;

Author according there are three dimensions or networks between the three forces in the response to the covid-19 pandemic in Bali. The first dimension is the economy, which through the customary village funds provided by the Provincial Government of Bali. This is in line with Bali Governor Wayan Koster program to provide Rp 50 million in aid per indigenous village for the handling of the Covid-19 pandemic, 
escaping without a hitch. Because, the Bali Parliament agreed to a total budget of Rp 74.65 billion for 1,493 indigenous villages throughout Bali plotted in the 2020 Change Budget, considering that indigenous villages are the vanguard of the Covid-19 pandemic (Tribunbali, 2020). The second dimension is politics. Politically, the existence of indigenous villages was strengthened in 2019 when local regulation number 4 in Bali Province was enacted. Positioning the indigenous village as the vanguard in the handling and supervision of the implementation of health protocols is an interesting thing. The third dimension, is the social dimension. The Provincial Government of Bali considers that culturally and culturally, indigenous villages have values that can govern indigenous people in accordance with Hinduism and customs in Bali. This strength is evident where some indigenous villages in Bali, carrying out large-scale social restrictions (PSBB) in the scope of the indigenous villages area in the event of a positive case against the indigenous people.

5. The government is quite a catalytic agent who gives directions, there is no need to run on its own. Related to this, the Provincial Government of Bali gives authority and budget (fiscal) for the indigenous village as a guard of health protocol supervision in Bali Province. These heavy and diverse loads and tasks are able to be decentralized well in accordance with the capacity of indigenous villages in supporting the revitalization and enforcement of health protocols. Optimization of local government performance is expected to be better realized, along with the division of authority and function in anticipation of the spread of covid-19 in Bali Province.

The five concepts try to reflect the implementation of synergy between the provincial government of Bali and the indigenous village in order to create good governance. The roles of actors are also tried to synergize positively, namely government, private and public. The third relationship must be balanced should not cause inequality on the one hand only. Local governments play a role in opening up a conducive and legal political environment. This is done When there is a polemic related to the position of indigenous villages to be part of the village government (village office), of course there will be inequality of authority than before especially to the indigenous villages. So it is expected to produce output in accordance with 
the creation of good governance in the region, especially in Bali. This can be explained in the scheme as follows:

\section{Figure 1.}

\section{Good local governance model}

Law no. 23 years 2014

Region Law Number 4 Year 2019

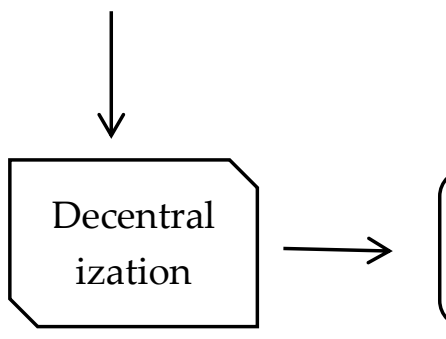

\section{Good local Governance}

- Local governments and indigenous villages

- Private

- Indiosannic nannlac and romminitiac

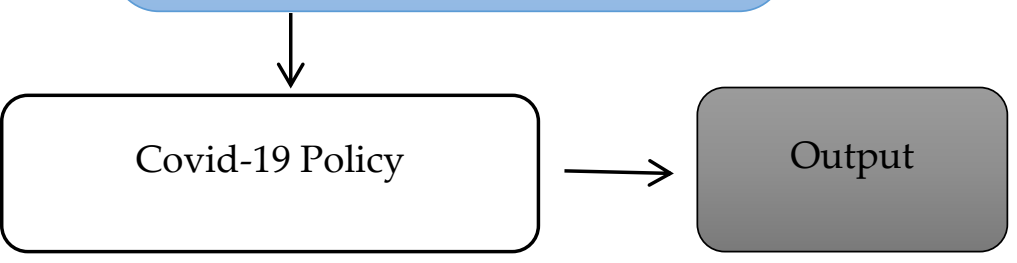

The authority given to The Indigenous Village is the duty and authority and the right to manage and take care of its own household. If attributed in the scheme, it is clear that good governance in the region is a form of implementation of autonomy based on indigenous villages in Bali. The formulation of a policy in the region is the result of good governance, namely the role of 3 domain (local governments including indigenous villages, private and indigenous peoples). As a monitoring of the performance of indigenous villages there are institutions that are attended by the indigenous village council at the provincial level of Bali. The role of the Indigenous Village Council as a "bridge" of aspiration for indigenous peoples across the local government, especially Province of Bali relates to aspirations, hopes and demands. Then it did not get there the role of the Indigenous Village Council acted as a check and balances against the indigenous village government. The actualization of the concept of good governance in the synergy of the Balinese provincial government with the indigenous village raises two strategic issues (Sidik, 2015). First, the issue of democratic governance, which is the village government derived from community participation, is managed with accountability and transparency by the community, and then utilized best for the responsiveness of the community itself. The village government referred more to the indigenous village, and the community in question is as an indigenous people. This communal bond became a force in supporting every policy carried out by the Bali provincial government, and vice versa. So when covid-19 pandemic management policy is given to 
indigenous villages as a leading cluster, it tends to be more effective. Second, the relationship between the governance elements in the village is based on the principles of alignment, balance, and trust in conducting village development collectively to achieve common good. The authority granted by the Bali provincial government to indigenous villages aims to provide balance, alignment and trust for the indigenous village government. The indigenous village government is no longer just related to indigenous affairs, culture, and Hinduism, but is also part of the implementation of local government policy to be more effective.

\section{Conclusion}

Based on the analysis that has been done, it provides a conceptual picture that indigenous villages, especially in the handling of covid-19 have a leading position in supporting the policies of the Bali provincial government. The relationship between the Bali provincial government and the indigenous village, more to the perspective of good local governance. The synergy that is awakened consists of various elements. First, the indigenous village as an institution and indigenous figure as an actor is involved in the policy of tackling covid-19. Second, the Bali provincial government is able to synergize power at the level of regional government in Bali, private parties, indigenous villages, communities and indigenous peoples in Bali. Third, build mutual support between local governments in Bali, indigenous villages, as well as indigenous peoples, for example with the supervision of health protocols. Fourth, the formation of a network based on economic dimensions, political dimensions and social dimensions. Fifth, the Government of Bali province became catalytic in the handler of covid-19, where synergies were awakened by giving authority to indigenous villages making rules in the sphere of indigenous areas. Surely that is in line with the covid19 confectionery, where the Bali provincial council is involved in surveillance.

\section{References}

AL-Habil, Wasim (2011). Governance and government in public administration. Journal of Public Administration and Policy Research. 3(5), 123-128. Retrieved from http://www.academicjournals.org/jpapr 
Mulayanto. (2009). Keberlakuan UU No 6 Tahun 2014 Tentang Desa di Bali dalam perspektif Sosilogi Hukum. Jurnal Mimbar Hukum, 27(3), 419. Retrieved from https:/jurnal.ugm.ac.id/jmh/article/download/15880/10489

Sidik, Fajar (2015). Menggali Potensi Lokal Mewujudkan Kemandirian Desa. Jurnal kebijakan dan administrasi publik, 19(2), 115-131. Retrived from https://journal.ugm.ac.id/jkap/article/view/7962/6528

Putra, Fadillah. (2005). Kebijakan tidak untuk publik. Resist Book, Yogyakarta.

Windia, Wayan, P.(2017). Desa adat di Bali sesudah berlakunya Undang-undang tentang Desa. Prosiding Seminar nasional Program Magister Hukum Universitas Udayana. Retrieved from https://simdos.unud.ac.id/uploads/file_penelitian_dir/adfa9b1dab8c0d4650d381184b03 90c3.pdf

Website :

Dharmada, Agung (2020, 28 Oktober). Harmonisasi Kegiatan Desa Adat ditengah Pandemi $\begin{array}{llll}\text { Covid-19. } & \text { Balipost. } & \text { Retrieved }\end{array}$ https://www.balipost.com/news/2020/10/28/154702/Harmonisasi-Kegiatan-Desa-AdatDitengah...html

Suadnyana, Sui Wayan (2020, 19 Oktober). Dewan Puji Kebijakan Koster Soal Penambahan Dana Bantuan ke Desa Adat untuk Penanganan Covid-19. Tribunnews Bali. Retrieved from https://bali.tribunnews.com/2020/10/19/dewan-puji-kebijakan-koster-soalpenambahan-dana-bantuan-ke-desa-adat-untuk-penanganan-covid-19 